\title{
Morphological Variation of Somatic Embryos of Coffea arabica L. During Some Sub-Culture Periods
}

\author{
Fitria Ardiyani ${ }^{1 *}$ and Sulistyani Pancaningtyas ${ }^{1)}$ \\ ${ }^{1}$ Indonesian Coffee and Cocoa Research Institute, Jl. P.B. Sudirman 90, Jember, Indonesia \\ ${ }^{*}$ Corresponding author: ardiyani.fitria@gmail.com \\ Received: 27 December 2016 / Accepted: 18 June 2017
}

\begin{abstract}
One of factors that affects the success of a plant cultivation using somatic embryogenesis method is the formation of somatic embryos from embryogenesis callus. This research aimed to study the effect of sub-culture period on quality and quantity of the somatic embryos of Coffea arabica. This research used explants of somatic embryos of Arabica coffee obtained from the leaves of $2 \mathrm{~K}$ Andungsari clone. The embryos were taken during embryogenesis callus phase using Murashige-Skoog culture media added with B5 vitamin and auxin hormone (2,4dichlorophenoxy acetic acid) $0.5 \mathrm{mg} / \mathrm{L}$ and sitokinin (benzyl amino purin) $1 \mathrm{mg} / \mathrm{L}$. Observation on somatic embryos obtained from the sub-culture period of 3,6, 9, 12 and 15 weeks. The parameters observed in this study included quantity and quality of the somatic embryos during each sub-culture period. Observations on quantity of the somatic embryos were conducted based on number of embryos per cluster, while quality was measured from the percentage of normal embryos, histological analysis, and morphological measurement on weight and size of the normal embryos. The result showed that the best quantity of somatic embryos was obtained from the sub-culture period of nine weeks with 18.4 somatic embryos per cluster. The best quality embryos were also obtained in the sub-culture period of nine weeks with the percentage of normal embryos $71.4 \%$. Histological analysis carried out on the somatic embryos obtained from sub-culture of three weeks period showed that the cells of the embryos were formed by living and solid cells which nucleus were clearly seen in the center of the cell, indicating that the embryos were formed by young tissues. Data of morphological parameters showed that normal embryos during the sub-culture period 3 to 15 weeks weighed around $0.23-0.78 \mathrm{mg}$ and length of around $0.18-0.25 \mathrm{~cm}$. The data can be used to predict number of explants and required time to produce certain number of normal embryos.
\end{abstract}

Keywords: Somatic embryos, sub-culture period, somatic embryogenesis, Coffea arabica

\section{INTRODUCTION}

Cultivation of Arabica coffee (Coffea arabica $\mathrm{L}$.) using clonal plants has been frequently studied, even presently it is being developed for larger commercial production. Micropropagation technique offers an alternative clonal system for the cultivation of both superior and hybrid coffee plants (Etienne et al., 2002). Presently, development of effective clonal cultivation of coffee plants is done using the somatic embryogenesis (SE) which is more popular than other in-vitro cultivation methods such as organogenesis, or axilary budding (Ogita et al., 2002; Girdhar et al., 2004; Gatica et al., 2008). Besides, it is used 
for superior seedlings cultivation at a large scale, this technique is also used for germplasm conservation and improvement of plant quality for it produces true-to-type plant seedlings at a large amount within a short period of time (Etienne et al., 2006). However, problems often occur in the implementation of this technique such as low regeneration level and low embryo quality which need protocol development to gain more efficient and reproduciple plant regeneration as the first step that should be establised in applying SE technology (Aslam et al., 2011). During in-vitro embriogenesis and morphogenesis, growth regulators have been widely used to induce new embryogenic cells, as used in tobacco cultivation (Ramage \& Williams, 2004). Ratio balance of each growth regulator should be a factor to be considered in every process of induction, development, and budding of embryos (Pan et al., 2003).

In-vitro embryogeneis process is a product of biotechnology advancement in manipulating a physiology and biochemical process during the growth of explants to be real plants (Quiroz-Figueroa et al., 2006). SE is a series of a process when somatic cells are growing to become somatic embryos through development of embryos without gamete fusion (Jiménez, 2005). All of the somatic cells in a plant contain series of information used to create complete and functional plants, in which somatic embryogenesis is a basic form of total genetic potential characteristics of high-order plant cells (Quiroz-Figueroa et al., 2006). SE process in coffee plants can be obtained from direct somatic embryogenesis of the proembryonic cells within the tissues found in the leaves during callus proliferation stage or indirect somatic embryogenesis through the formation of embryogenic callus (Jiménez, 2001; Molina et al., 2002). Somatic embryogenesis in Coffea canephora was firstly studied by Staristsky
(1970) and in Coffea arabica L. by Söndahl \& Sharp (1977) which were then followed by some researchers including Etienne $e t$ al. (2002), Figueroa-Quiroz et al. (2002), Oktavia et al. (2003), Priyono (2004), Giridhar et al. (2004), Albarrán et al. (2005), Samson et al. (2006), Andrés et al. (2008), Arimarsetiowati (2011) and Ibrahim et al. (2013). The implementation of SE protocol is done in Arabica coffee using the explants which are taken from the leaf explants as done by Gatica et al. (2008) through an indirect embryogenesis method, and Van Boxtel \& Berthouly (1996), Quiroz-Figueroa et al. (2001), Arimarsetiowati (2011) and Ibrahim et al. (2013) using the indirect embryogenesis method.

A key process to the success of the use of SE method is the formation of embryos from embryogenic callus. Multiplication of somatic embryos can be done by repreating the sub-culture method done in solid culture media, yet this method only produces few number of embryos. In-vitro cultivation of tea plants in solid culture media often causes a number of inappropriacy within the growh of the somatic embryos such as morphological, anatomical and physiological changes in the plants tissue (Tahardi et al., 2003). This obstacle often occurs in plant cultivation using in-vitro method (Kevers et al., 1984; Ziv, 1991; Debergh et al., 1992). This phenomena also often happens in massivecultivation using liquid medium culture method (Olmos, 2006). Other problems in the application of tissue culture is the degradation of quality and quantity of the embryos as it comes to further sub-culture periods. Pancaningtyas (2013) mentioned that the quantity of cocoa embryos tended to decline in every sub-culture period, causing significant loss and other problems in the attempts of massive commercial cultivation. Bornhoff $\&$ Harst (2000) also stated that the quality 
of the somatic embryos in grape plants has significant effect on regeneration of the plants using in-vitro technique. Embryo maturation and its growth generally decline in further sub-culture periods. The long process of sub-culture in pine tree causes morphological degradation to the immature embryos which indicates the weakened ability to create normal somatic embryos (Breton et al., 2006). Latest study conducted by Peng et al. (2015) showed that somatic variation in Tetastring hemsleyanum experienced improvement within longer sub-culture period in the early sub-culture stage. This variation may occur due to the accumulated auxin hormone IAA at high concentration.

Those references are used as the starting point of this study to understand the effect of sub-culture periods toward quality and quantity of somatic embryos of Arabica coffee. One of the Arabica coffee clones which has produced plantlets is Andungsari $2 \mathrm{~K}$ clone. This research investigated morphological and histological characteristics of Arabica coffee in every sub-culture period that can be used as a guidance to determine the most appropriate sub-culture frequency in the production of somatic embryogenesis.

\section{MATERIALS AND METHODS}

This research was carried out in Biotechnology Laboratory of Indonesian Coffee and Cocoa Research Institute using Coffea arabica $\mathrm{L}$. from the clone of Andungsari $2 \mathrm{~K}$. This clone is one of superior Arabica coffee clones cultivated by farmers and has been legally distributed. In the somatic embryogenesis production, young leaves of Arabica coffee plant from the clone AS $2 \mathrm{~K}$ were used as explants.

The explants were firstly strerilized using $2 \mathrm{~g} / \mathrm{L}$ fungicide, $2 \%$ sodium hypochloride, and $70 \%$ alcohol as the sterilants for 20 30 minutes. After they were sterilized, the explants were put into induction media or basic media Murashige-Skoog added with 0,5 mg/L 2,4-dichlorophenoxy acetic acid, $1 \mathrm{mg} / \mathrm{L}$ benzyl amino purin and B5 vitamin. The incubation of each induction process was done around 2-3 months until embryogenic callus were produced. The embryogenic callus were incubated for the mutiplication process in the culture medium of the modified MS on MS0 added with $1 \mathrm{mg} / \mathrm{L}$ Benzyl Amino Purin. In this step, embryogenic callus was able to produce multiplied number of embryos during some sub-culture periods. The subculture period was done once in three weeks. This research used completely randomized design with 10 replications. The explants used in this study were embryos produced within some sub-culture periods including the embryos from sub-culture period 3, 9, 12, and 15 weeks.

Observation was done to see quantity and quality of somatic embryos in each of sub-culture period. Observation on the quantity of somatic embryos was done by counting number of embryos found in a cluster. Whilst the quality of the somatic embryos was measured from the percentage of normal embryos, embryo histological analysis and morphological measurement which included weight and length of normal somatic embryos.

Histological analysis was done in Labroratory of Plant Growth Structure, Faculty of Biology, Gadjah Mada University to see the condition of the cells in each embryo in every sub-culture period. The analysis used paraffin with single coloring (safranin $1 \%$ and fast green $1 \%$ ) toward the across and crosswide views of Arabica coffee embryos (Jensen, 1962). From these parameters, the quantity and quality of embryos produced in each sub-culture period can be observed. 


\section{RESULTS AND DISCUSSION}

Embryos are formed out of apical embryogenic callus cells that grow to be embryos. Pardal (2002) stated that in proliferation process, a cell and a group of small cells found in the surface primary embryos will grow to new somatic embryos. The embryo formation from embryogenic callus is supported by auxin and cytokinin hormones present in the culture medium. Auxin hormone in in-vitro culture triggers cell division, stimulates growh of callus and stregthens apical dominance. George et al. (2008) explained that cells responsed toward the auxin caused differentiation and stimulate cell division. Number of embryos produced in each subculture period is presented in Figure 1.

It can be seen that in early formation stage of embryogenic callus, embryos were produced at relatively low number. However, the number increased in further subculture periods which also increased number embryos. Out of the five sub-culture periods, the highest embryo number was obtained in the sub-culture of 9 weeks. In this period, number of embryos produced by embryogenic callus reached about 18.36 embryos/ cluster. In further period, this number declined until sub-culture period of 15 weeks. Callus that have gone through several sub-culture periods will have lower multiplication ability and result lower number of embryos. Biswas et al. (2002) stated that new callus had greater ability to produce shoots compared to callus that have gone through repeated subcultures or long sub-culture period due to the effect of treatments and radiation. New callus might contain polyamine or a substance which have major role during rapid regeneration process. Priyono (1992) conducted a study on Arabica coffee which showed that reproduction ability of somatic embryos increased in the second sub-culture period and decreased after the sixth sub-culture.

Number of embryos produced by embryogenic callus in every sub-culture period highly depends on the ability of cells and the quality of culture medium. Embryogenic callus is formed by cells which have total genetic potential characteristics which are expressed when the cultivation uses compatible culture

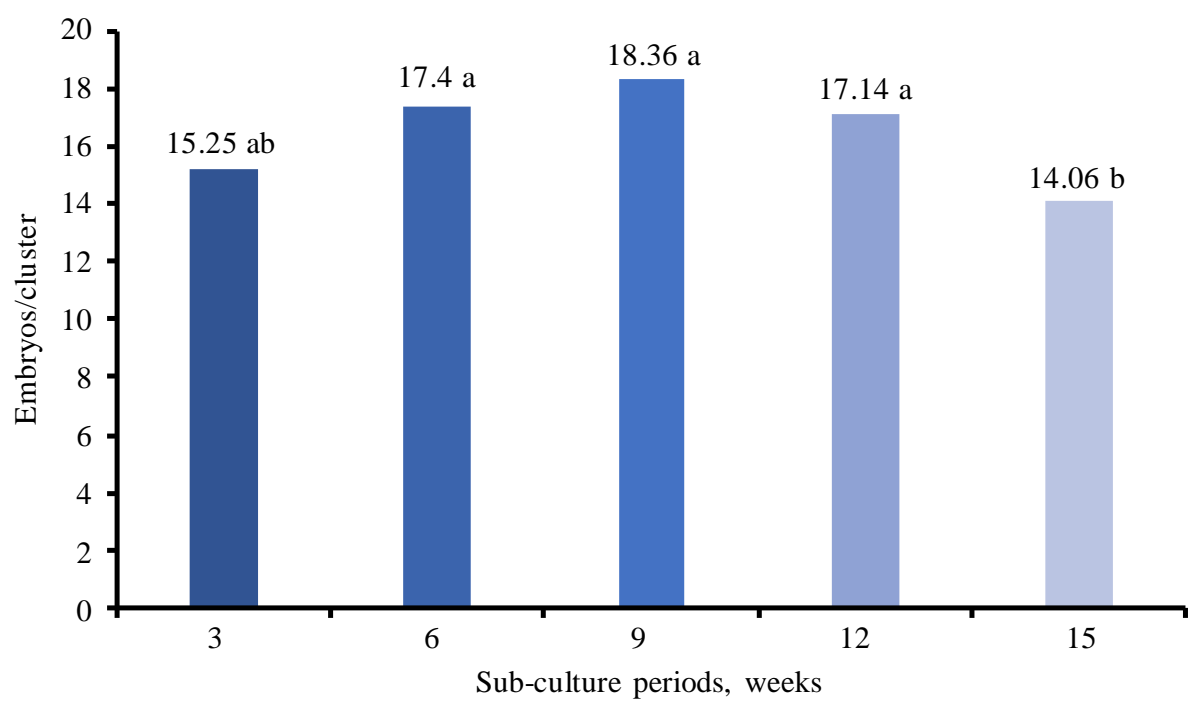

Figure 1. Number of embryos for five sub-culture periods Notes: Data in histogram followed by the same letter are not significanly different according to Duncan 5\%. 
medium containing enough growth nutrients. Precise composition of culture medium affets the success of the callus to produce embryos and utilize hormones. In SE of Arabica coffee, embryogenic callus was induced to the culture medium that contains auxin hormone 2,4dichlorophenoxyacetic acid and cytokinin (benzyl amino purin). Those hormones stimulates the growth of embryogenic callus to become embryos. Wattimena (1992) highlighted that the culture medium determined the regeneration of the callus. Balance nutrition contained in a culture media plays an important role for callus formation and its differentiation to form planlets. Explant morphogenesis depends on the balance proportion of auxin and cytokinin in the culture media and interaction among the endogenous growth factors of the plants as well as exogenous growth factors absorbed from the culture media.

Embryos produced in every sub-culture period are young and vulnerable embryos that may grow abnormally. Normal embryos are embryos that fully grow and having potential roots and stem. Normal embryos are also well-structured like globular. There are four phases of somatic embryo tissue differentiation to be plant plantlets which are globular, heart-shaped, torpedo, and cotyledon phases (Khumaida \& Handayani, 2010). On the other hand, embryos which do not possess those characteristics are experiencing abnormal growth (Figure 2).

The embryos produced in this study included normal and abnormal embryos. Percentage of normal embryos was one of the parameters to measure the quality of embryos in every sub-culture period as illustrated in Figure 3.

From the whole number of embryos produced in every sub-culture period, it can be seen that not all of the embryos grew well and successfully became cotyledonary embryos Arabica coffee. In the sub-culture period of three weeks, percentage of normal embryos was $42.53 \%$ and increased until the end of the sub-culture period of nine weeks reaching up to $71.43 \%$. However, starting from the subculture period of 12 weeks percentage of normal embryos declined until sub-culture period of 15 weeks, leaving only $27.03 \%$ normal embryos. It is implied that the highest number of normal embryos was produced in the subculture period of nine weeks.

Normality of the embryos highly influence the further growing phase of the embryos; germinating phase. Normal embryos grow to be individuals with buds and roots that will grow to be Arabica coffee plantlets, however abnormal embryos fail to grow as cotyledonary embryos or plantlets. Abnormal condition provide negative effects for the normal
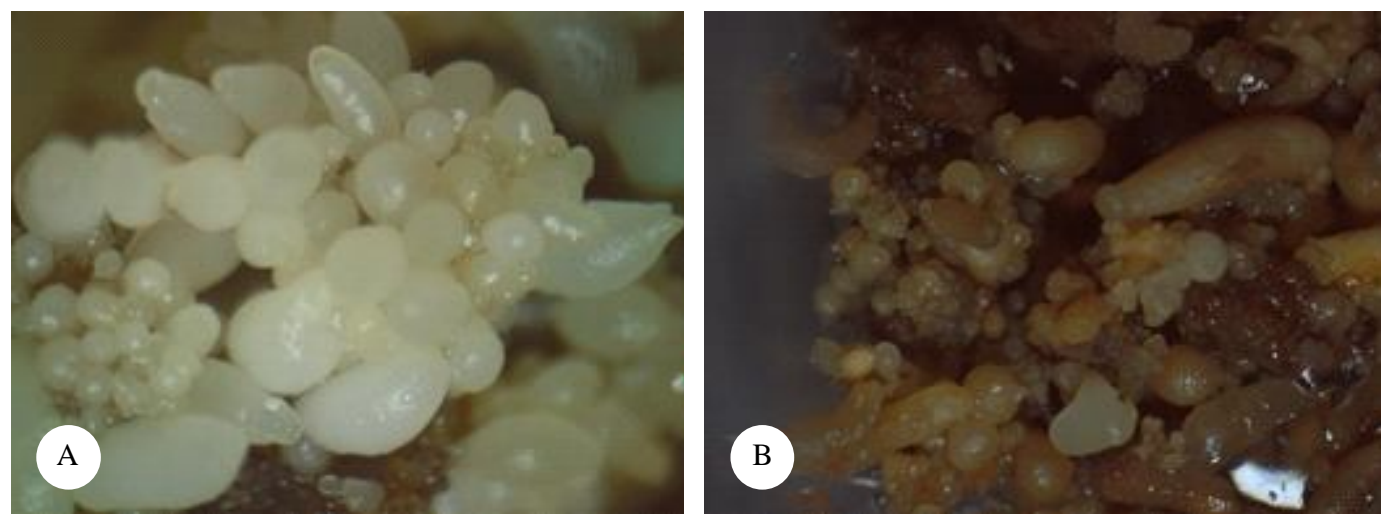

Figure 2. Normal embryos (a); abnormal embryos (b) 


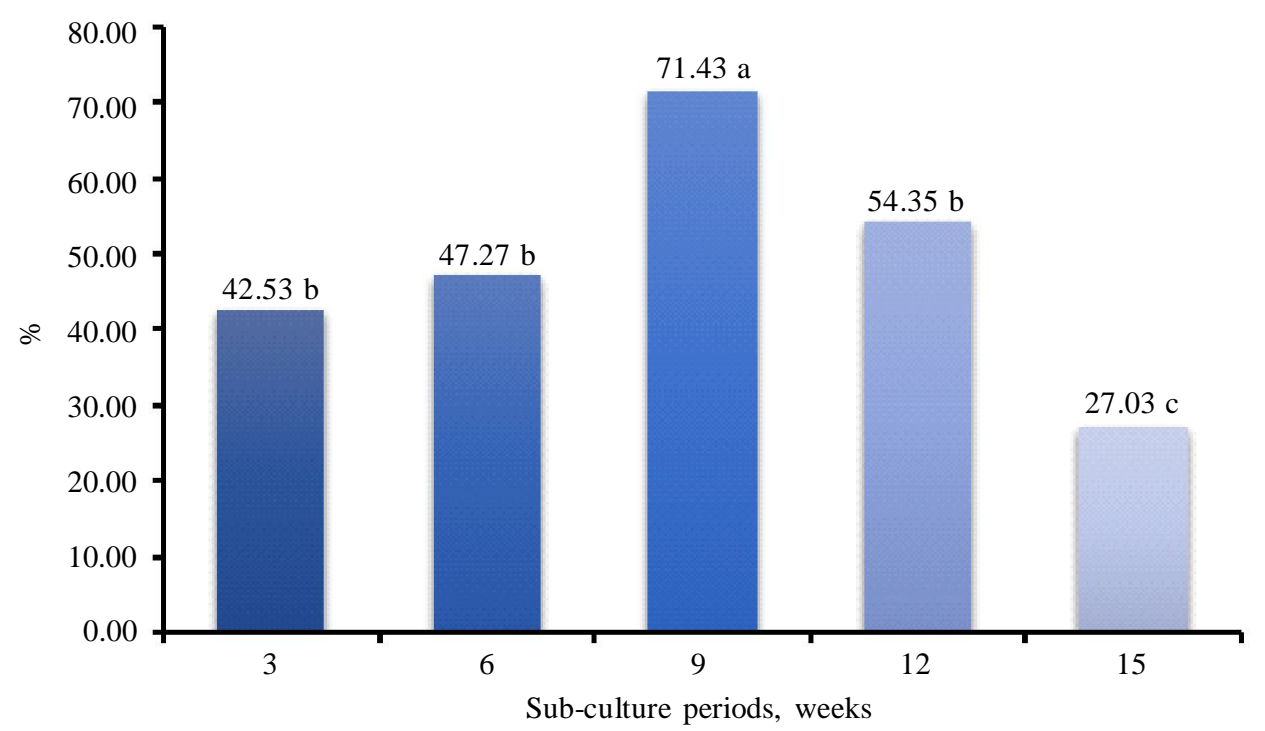

Figure 3. Percentage of normal embryos for five sub-culture periods

Notes: Data in histogram followed by the same letter are not significanly different according to Duncan 5\%.

embryos since both normal and abnormal embryos take nutrients from the culture medium. Pancaningtyas (2013) stated that if embryos grow within various phases at the same length of time, embryos will compete against each other that will cause abnormal growth. The inappropiate growth will prevent the embryos from growing during the early phases which also increases the tendency to grow abnormally in the next phases.

As seen in Figure 3, in sub-culture period of 15 weeks, number of normal embryos reached only $27.03 \%$, indicated that the proportion of normal embryos tended to decline after the sub-culture period of 12 weeks. The more frequent the embryos undergo subculture, the higher the level of abnormality of the embryos and the higher the embryogenic callus proliferation (Pancaningtyas, 2013). In addition, in a study on Siamese orange (Citrus nobilis Lour) CV. Simadu, Kosmiatin et al. (2014) stated that even though the embryos can be produced in a massive number, the number of morphologically abnormal embryos is greater than the normal ones. Embryo abnormality is assumed derived from the accumulation of excessive protein stored as the result of biotin activity as co-factor of protein synthesis and organic nitrogen availability which can be easily absorbed by the plants (Dodeman et al., 1997).

One of the factors that likely caused abnormal embryo growth was the use of auxin which control embryogenesis process through acidification in the cytoplasm and/ or cell walls (Kutschera, 1994). Moreover, Reinert (1958) reported that auxin had significant function in cell wall regeneration process in some plant species such as in the embryogenesis of carrots. Auxin, including the 2.4-D at the precise concentration is able to stimulate growh of embryo, thought high auxin concentration may also rise the chance of mutation as well as high concentration of auxin accumulation found in the embryos from repeated sub-culture. This view goes 
in line with the one confirmed by Lazzeri et al. (1987) who stated that the frequency of sub-culture affected the frequency of normal embryo formation, which in the preculture in medium containing 2.4 D improved embryogenesis efficiency of the NAA culture medium, yet it decreased the frequency of normal embryo formation.

Abnormal embryo growth in every subculture period can be predicted from the condition of Arabica coffee embryo cells. Normal embryos contain cells that can grow to be cotyledonary embryos in further steps. The condition of normal embryo cells in every sub-culture period can be seen from cross-section observation of Arabica coffee embryos as presented in Figure 4.
Figure 4 shows the condition of normal embryos in every sub-culture period. Normal cells are the ones with living cells which contain plasma and clearly visible nucleolus, formed by solid meristematic tissue with visible amylose, and having a number of prospective shoots and more solid vascular tissue (Ardiyani, 2015).

Figure 4 presents normal embryos in the sub-culture period nine weeks. These embryos are formed by solid and massive smaller cells and some loosely big cells. All of those cells are alive, yet their nucleolus are not clearly visible for most of the cells have their nucleolus in the edges. In the $3^{\text {rd }}$ week of sub-culture period, embryogenic start to produce normal embryos at relatively low
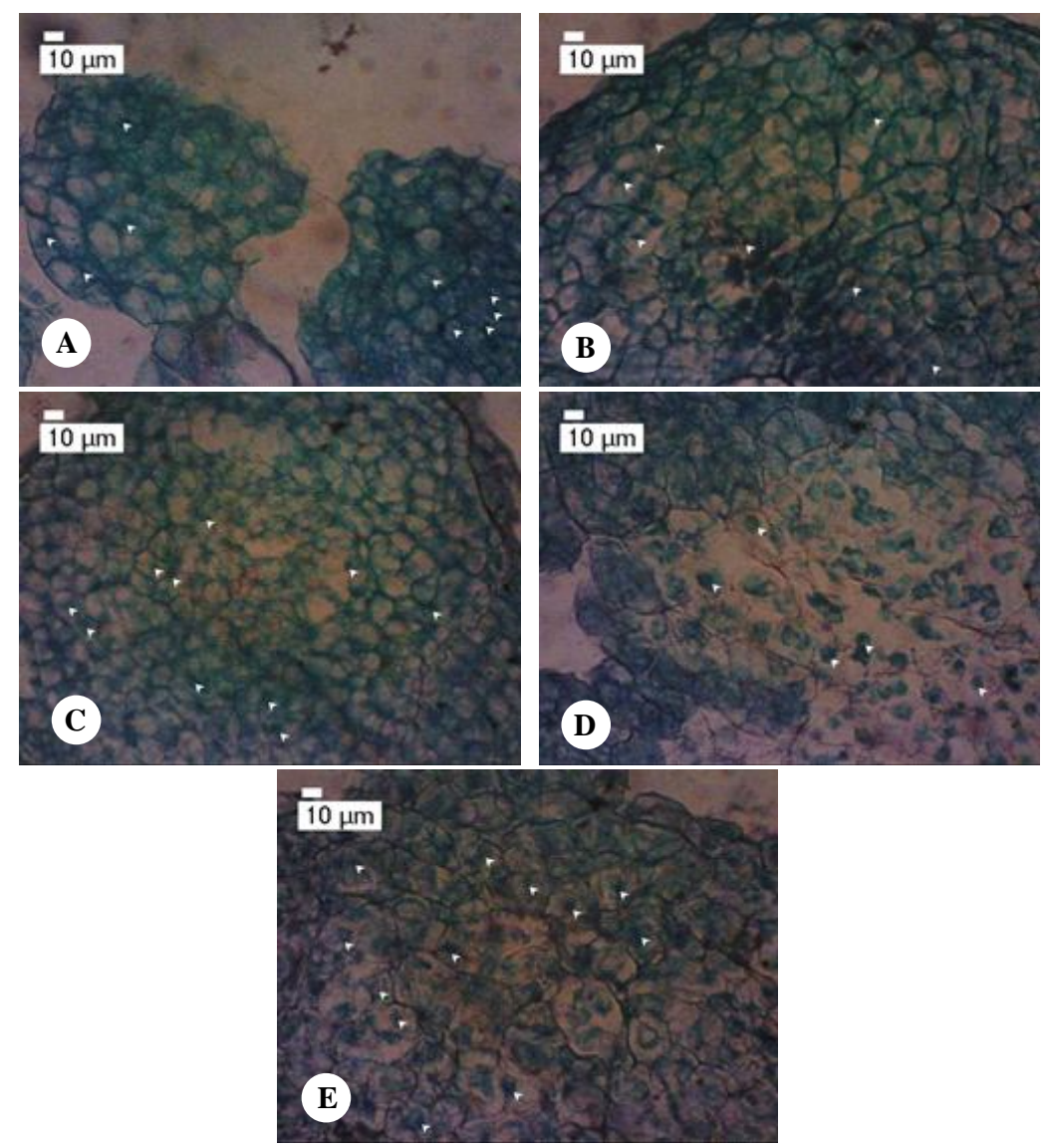

Figure 4. Histology of normal embryo for several sub-culture period $(\mathrm{A}=3$ weeks; $\mathrm{B}=6$ weeks; $\mathrm{C}=9$ weeks; D = 12 weeks; $\mathrm{E}=15$ weeks) 
number. This is due to some meristematic cells that are not yet fully grown within the tissue. As found in ginger plants, histology observation done toward embryogenic cell mass shows that globular embryos start to be formed in the proliferation medium after two weeks of culture (Rostiana \& Syahid, 2007).

It can be seen in Figure $4 b$ (normal embryos in the $6^{\text {th }}$ week of sub-culture period) that the embryos were formed by more solid and massive alive cells with clearly visible nucleolus. Most of the cells had their nucleolus in the center, yet some still had their nucleolus in the edge of the cells. This showed that some cells had the ability to grow as new individuals. Meanwhile, Figure $4 \mathrm{c}$ showed the condition of normal embryos in the $9^{\text {th }}$ week of sub-culture period which were formed by solid massive cells with smaller size. Those cells are alive and their nucleolus are visibly seen in the center of the cell. This shows that the tissues were young and meristematic. Meristematic cells were identified by more solid rooms inside the cells with clearly visible nucleolus, absorb stronger color, solid cytoplasm and high frequency of cell division activities (Kasi \& Sumaryono, 2008).

Figure $4 \mathrm{~d}$ (normal embryos in the $12^{\text {th }}$ week of sub-culture period) showed that embryos were formed by loose cells yet with large cell size. The nucleolus were clearly visible even though some nucleolus were still located in the edge of the cells. The same phenomena can be seen in Figure 4e (normal embryos in the $15^{\text {th }}$ week of sub-culture period) in which it is shown that embryos are formed by less number loose but large cells. These cells are alive cells since the nucleolus are clearly seen. However, their meristematic characteristics have been weakened, shown by the nucleolus moved to the edges of cells. Embryos with this condition are no longer able to grow optimally.
Normal embryos of Arabica coffee formed in earlier sub-culture period tended to have meristematic cells that support the embryos to grow as cotyledonary embryos and become coffee plantlets. On the other hand, in the later sub-culture period, cells that form the embryos have weakened meristematic ability, causing the embryos to grow abnormally. The same phenomena are also found in the case of sugar cane embryos and date fruit embryos (Sané et al., 2006). Kasi \& Sumaryono (2008) stated that embryogenic cells in sugarcane plants are meristem cells that form clusters which are covered by polysaccharide layer, in which each cluster will grow as a new individual.

Besides conducting histology observation on the normal embryos in every sub-culture period, morphology observation on the normal embryos of Arabica coffee clone AS 2K was also conducted. The morphological parameters observed in this study included weight (Figure 5) and length (Figure 6). Embryos that have normal morphological condition grow as cotyledonary embryos and plantlets in further somatic embryogenesis steps.

From the result of observation, it was found that there was no significant difference on the weight of normal embryos in the subculture period 6 to 15 weeks at $0.68 \mathrm{mg}-$ $0.78 \mathrm{mg}$. Significant difference was found only in the normal embryos produced in the sub-culture period three weeks at $0.23 \mathrm{mg}$, because in the earlier steps of embryo formation, the cells that formed the embryos were not yet completely grown. Besides, the use of cytokinins hormone in the culture medium affected the cell division and morphological growth of the embryos. The use of auxin and cytokinins was able to stimulate the growth of Arabica coffee embryos. The size of plant tissues in the culture medium without cytokinins grew but cell division did not occur. Ibrahim et al. (2012) found in his study that Arabica coffee cultured in a culture media 


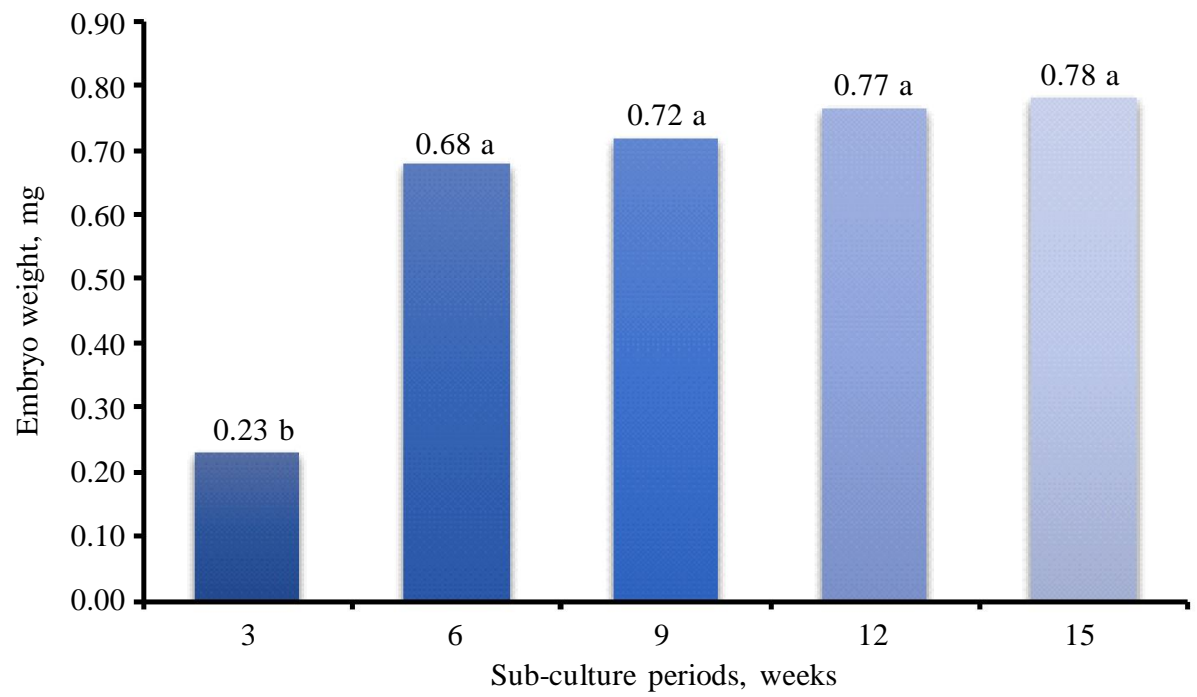

Figure 5. Weight of embryos for five sub-culture periods

Notes : Data in histogram followed by the same letter are not significanly different according to Duncan 5\%.

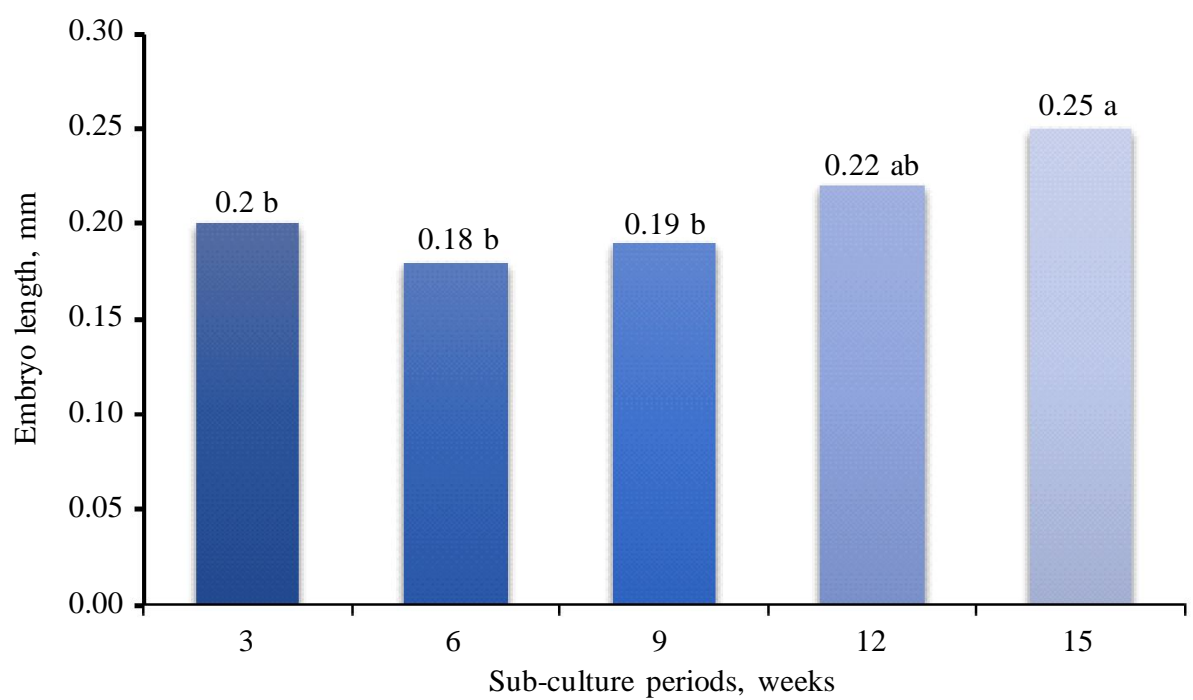

Figure 6. Length of normal embryos for five sub-culture periods

Notes : Data in histogram followed by the same letter are not significanly different according to Duncan $5 \%$.

added with auxin and cytokinin hormones gained more weight after being cultured for two months.

The same phenomena also occurred for length of the embryos. Normal embryos grow from the prospective shoots and roots. Normal embryos also grow as cotyledon embryos before they become as Arabica coffee planlets.

It can be implied from a Figure 6 that the length of normal embryos was around $0.18-0.25 \mathrm{~cm}$. In the sub-culture period 6 and 9 weeks, the length was smaller. However, in the further sub-culture periods, the 
length of embryos started to grow again. This condition is also found in the sago plant. Kasi \& Sumaryono (2008) mentioned that the average size of sago embryos in the $3^{\text {rd }}$ week was decreased due to the competition that occurred among the embryos in a cluster. Even though the length of normal embryos in every sub-culture period was significantly different, those normal embryos have gone through the cotyledon phase indicated by the growth of prospective shoots and roots. The growth of the length of embryos occurred as the effect of cell division and new cell growth. This mechanism generally occurs in the apical meristem and stem, making the plants grow higher (Widiastoety, 2014).

\section{CONCLUSIONS}

The best quantity of the embryos is produced in the sub-culture nine weeks period with average value of 18.36 . Whilst, the best quality of embryos is produced in the sub-culture 9 weeks period with a percentage of normal embryos at $71.43 \%$. This result is supported by the result of histology analysis on the embryos produced in the sub-culture of that period. Meanwhile, observation on morphological parameters of the embryos shows that the weight of normal embryos ranges from $0.23-0.78 \mathrm{mg}$ and the length of normal embryos is around $0.19-0.25 \mathrm{~cm}$.

\section{REFERENCES}

Albarrán, J.G.; B. Bertrand; M. Lartaud \& E. Etienne (2005). Cycle characteristics in a temporary immersion bioreactor affect regeneration, morphology, water and mineral status of coffee (Coffea arabica L.) somatic embryos. Plant Cell Tissue and Organ Culture, 81, 27-36.

Arimarsetiowati, R. (2011). Pengaruh auksin 2,4-D dan sitokinin 2-ip terhadap pembentukan embriogenesis somatik langsung pada eksplan daun Coffea arabica L. Pelita Perkebunan, 27, 68-77.

Aslam, J.; A. Mujib \& M.P. Sharma (2011). Influence of freezing and non-freezing temperature on somatic embryogenesis and vinblastine production in Catharanthus roseus (L.). Acta Physiologiae Plantarum, $33,473-480$

Biswas, B.; A. Chowdhurry; B. Bhattacharya \& Mandal (2002). In-vitro screening for increases drought tolerance in rice. In-vitro Cellular and Developmental Biology Plant, 38, 525-530.

Bornhoff, B. \& M. Harst (2000). Establishment of embryo suspension culture of grapevines (Vitis L.). Vitis, 39, 27-29.

Breton, D.; L. Harvengt; J.F. Trontin; A. Bouvet \& J.M. Favre (2006). Long-term subculture randomly affects morphology and subsequent maturation of early somatic embryos in maritime pine. Plant Cell Tissue and Organ Culture, 87, 95-108.

Debergh, P.; J. Aitken-Christie; D. Cohen; B. Grout; S. Von Arnorld; R. Zimmerman \& M. Ziv (1992). Reconsideration of the term "Vitrivication" as used in micropropa-gation. Plant Cell Tissue and Organ Culture, 30, 135-140.

Dodeman, V.L.; G. Ducreux \& M. Kreis (1997). Zygotic embryogenesis versus somatic embryogenesis. Journal of Experimental Botany, 48, 1493-1509.

Etienne, H.; F. Anthony; S. Dussert; D. Fernandez; P. Lashermes \& B. Bertrand (2002) Biotechnological applications for the improvement of coffee (Coffea arabica L.). In vitro Cellular and Developmental Biology Plant, 38, 129-138.

Etienne, H.; E. Dechamp; D. Barry-Etienne \& B. Bertrand (2006). Bioreactors in coffee micropropagation. Brazilian Journal of Plant Physiology, 18, 45-54.

Gatica, A.M.; E.G. Arrieta \& A.M. Ezpinoza (2008). Direct somatic embryogenesis 
in Coffea arabica L. L. cvs.'Catura' and 'Catuai': Effect of triacontanol, light conditions and medium consistency. Agronomia Costaroiecense, 32, 140-145.

George, E.F. ; A.H. Michael \& D.K. Geert-Jan (2008). Plant Propagation by Tissue Culture Volume 1. Chapter : Plant Tissue Culture Procedure. Springer. Dordrecht. Netherlands.

Giridhar, P.; V. Kumar; E.P. Indu; Ravishankar \& A. Chandrasekar (2004). Thidiazuron induced somatic embryogenesis in Coffea arabica L. and Coffea canephora P. ex Fr. Acta Botanica Croatica, 63, 25-33.

Ibrahim, M.S.D; S. Hartati; Rubiyo; A. Purwito \& Sudarsono (2013). Embryogenic calli induction and regeneration potential of arabica coffee by 2,4-dichlorophenoxyacetic acid and 6-benzyladenine. Buletin Ristri, 4, 91-96.

Jensen W.A. (1962). Botanical Histochemistry: Principles and Practice. W.H. Freeman \& Co. San Francisco.

Jiménez, V. (2001). Regulation of in-vitro somatic embryogenesis with emphasis on the role of endogenous hormones. Brazilian Journal of Plant Physiology, 13, 196-223.

Jiménez, V. (2005). Involvement of plant hormones and plant growth regulators on in vitro somatic embryogenesis. Plant Growth Regulors, 47, 91-110.

Kasi, P. D. \& Sumaryono (2008). Perkembangan kalus embriogenik sagu (Metroxylon $s a g u$ Rottb.) pada tiga sistem kultur in vitro. Menara Perkebunan, 76, 1-10.

Kevers, C.; M. Coumans; M.F. Coumans-Gilles \& T. Gaspar (1984). Physiological and biochemical events leading to vitrification of plants cultured in vitro. Physiology Plant, 61, 69-74.

Khumaida, N. \& T. Handayani (2010). Induksi dan proliferasi kalus embriogenik pada beberapa genotipe kedelai. Jurnal Agronomi Indonesia, 38, 19-24.

Kosmiatin, M.; A. Purwito.; G.A. Wattimena \& I. Mariska (2014). induksi embriogenesis somatik dari jaringan endosperma jeruk siam (Citrus nobilis Lour.) CV. Simadu. Jurnal Agronomi Indonesia, 42, 44-51.

Kutschera, A. (1994). The current status of the acid-growth hypothesis. New Phytologist, 126, 549-569.

Lazzeri, A.; D.F. Hildebrand \& G.B. Collins (1987). Soybean somatic embryogenesis: Effects of hormones and culture manipulations. Plant Cell Tissue and Organ Culture, 10, 197-208.

Molina, D.; M.E. Aponte; H. Cortina \& G. Moreno (2002). The effect of genotype and explant age on somatic embryogenesis of coffee. Plant Cell Tissue and Organ Culture, 71, 117-123.

Ogita, S.; H. Uefuji; Y. Choi; T. Hatanaka; M. Ogawa; Y. Yamaguchi; N. Koizumi \& H. Sano (2002). Genetic modification of coffee plants. Journal of Plant Biotechnology, 3, 91-94.

Olmos, E. (2006). Prevention of hyperhydricity in plant tissue culture. p. 285-288. In: Teixeira da Silva, J.A. (Ed). Floriculture, Ornamental and Plant Biotechnology. Spain.

Pan, Z.G.; C.Z. Liu; S.J. Murc; M. El-Demerdash \& P.K. Saxena (2003). Plant regeneration from mesophyll protoplasts of the Egyptian medicinal plants Artemisia judaica L. and Echinops spinosissimus Turra. Plant Science, 165, 681-687.

Pancaningtyas, S. (2013). Evaluasi kuantitas dan hiperhidrisitas embrio somatik kakao pada kultur padat, kultur cair, dan sub kultur beruntun. Pelita Perkebunan, 29, 10-19.

Pardal, S.J. (2002). Perkembangan penelitian regenerasi dan transformasi pada tanaman kedelai. Buletin AgroBio. 5, $37-44$.

Peng, X.; T.T. Zhang \& J. Zhang (2015). Effect of subculture times on genetic fidelity, endogenous hormone level and pharmaceutical potential of Tetrastig hemsleyanum callus. Plant Cell Tissue and Organ Culture, 122, 67-77. 
Priyono (2004). Kultur in vitro daun kopi untuk mengetahui kemampuan embriogenesis somatik beberapa varietas kopi. Pelita Perkebunan, 20, 110-122.

Priyono (1994). Pengaruh subkultur beruntun pada kemampuan reproduksi embrio somatik kopi Arabika. Pelita Perkebunan, $8,50-54$.

Quiroz-figueroa, F.R.; M. Mendez-zeel; A. Larquesaavedra \& V.M. Loyola-vargas (2001). Picomolar concentrations of salicylates induce cellular growth and enhance somatic embryogenesis in Coffea arabica L. tissue culture. Plant Cell Reports, 20, 679-684.

Quiroz-figueroa, F.R.; C.F.J. Fuentes-cerda; R. Rojas-herrera \& V.M. Loyola-vargas (2002). Histological studies on the developmental stages and differentiation of two different somatic embryogenesis systems of Coffea arabica L. Plant Cell Reports, 20, 1141-1149.

Ramage, C.M. \& R.R. Williams (2004). Cytokinin induced abnormal shoot regeneration is associated with elevated knottedl type homeobox gene expression in tobacco. Plant Cell Report, 22, 919-924.

Reinert, J. (1958). Untersuchungen uber die morphogenese an gewebenkulturen. Berichte der Deutschen. Botanischen Gesellschaft, 7, 1-15.

Rostiana, O. \& S.F. Syahid (2007). Pengaruh media dasar MS dan N6 terhadap perkembangan embrio somatik pada kultur meristem jahe (Zingiber officinale Rosc.). Berita Biologi, 8, 343-353.

Samson, N.P.; C. Campa; L.M. Gal; G. Noirot; T.S. Thomas; A. Lokeswari \& D. Kochko (2006). Effect of primary culture medium composition on high frequency somatic embryogenesis in different Coffea species. Plant Cell Tissue and Organ Culture, 86, 37-45.
Sané, D.; F. Aberlenc-Bertossi; Y.K. GassamaDia; M. Sagna; M.F. Trouslot; Y. Duval \& A. Borgel (2006). Histocytological analysis of callogenesis and somatic embryogenesis from cell suspension of date palm (Phoenix dactylifera). Annals of Botany, 98, 301-308.

Staritsky, G. (1970). Embryoid formation in callus tissues of coffee. Acta Botanica Neerlandica, 19, 509-514.

Tahardi, J.S.; I. Riyadi \& W.A. Dodd (2003). Enhancement of somatic embryo development and plantlet recovery in Camellia sinensis by temporary liquid immersion. Jurnal Biotek Pertanian, $8,1-7$.

Van boxtel, J. \& M. Berthouly (1996). High frequency somatic embryogenesis from coffee leaves: factors influencing embryogenesis, and subsequent proliferation and regeneration in liquid medium. Plant Cell Tissue and Organ Culture, 44, 7-17.

Wattimena, G.A. (1992). Bioteknologi Tanaman. Direktorat Jenderal Pendidikan Tinggi. Pusat Antar Universitas IPB. Bogor.

Widiastoety, D. (2014). Pengaruh auksin dan sitokinin terhadap pertumbuhan planlet anggrek Mokara. Journal of Horticultural Research. 24, 230-238.

Ziv, M. (1991). Vitrification: Morphological and physiological disorder of in vitro plant. p. 45-69.In:P.G.Debergh \&R.H.Zimmerman (Eds.). Micropropagation: Technology and Application. Kluwer, Dordrecht, Netherlands.

$$
* * 0 * *
$$

